\title{
CRYSTAL STRUCTURE OF BIS-(AQUATRIMETHYLSTANNYL)OXALATE $\left[\mathrm{Me}_{3} \mathrm{Sn}\left(\mathrm{H}_{2} \mathrm{O}\right)\right]_{2} \mathrm{C}_{2} \mathrm{O}_{4}$
}

\author{
Libasse Diop, ${ }^{1}$ Mary F Mahon, ${ }^{2}$ Kieran C Molloy ${ }^{* 2}$ and Mamadou Sidibe ${ }^{1}$ \\ ${ }^{1}$ Department de Chimie, Faculte des Sciences et Techniques, \\ Universite Cheikh Anta Diop de Dakar, Dakar, Republique du Senegal \\ ${ }^{2}$ School of Chemistry, University of Bath, Claverton Down, Bath BA2 7AY, UK
}

\begin{abstract}
The structure of bis-(aquatrimethylstannyl)oxalate has been determined and found to contain metal atoms in a trans $-\mathrm{O}_{2} \mathrm{SnC}_{3}$ environment. Each tin atom is bonded axially by one water and a monodentate oxalate, while the lattice structure is dominated by hydrogen bonds rather than intermolecular carboxylate bridges.
\end{abstract}

\section{Introduction}

We have been interested for some time in the structural chemistry of organotin(IV) derivatives of mono- and di-basic oxyanions $\left(\mathrm{ClO}_{4}{ }^{-}, \mathrm{NO}_{3}{ }^{-}, \mathrm{CrO}_{4}{ }^{2-}, \mathrm{SeO}_{4}{ }^{2-} \mathrm{etc}\right)$, a group of compounds which have been largely overlooked crystallographically. In addition to the known structure determinations of $\left(\mathrm{R}_{3} \mathrm{Sn}\right)_{2} \mathrm{CO}_{3}(\mathrm{R}=\mathrm{Me}$, $\mathrm{Bu})(1,2)$ and $\mathrm{Me}_{3} \mathrm{SnNO}_{3}\left(\mathrm{H}_{2} \mathrm{O}\right)(3)$, we have reported the structure of $\left(\mathrm{Me}_{3} \mathrm{Sn}\right)_{2} \mathrm{SO}_{4} \cdot 2 \mathrm{H}_{2} \mathrm{O}(4)$ and, more recently, $\left(\mathrm{Me}_{3} \mathrm{Sn}\right)_{2} \mathrm{SeO}_{3} \cdot \mathrm{H}_{2} \mathrm{O} .(5)$ Organotin oxalates are a group of compounds which come into this general area of interest and on which we have previously reported spectroscopic data (6). From the structural point of view both neutral and anionic tin oxalate complexes are known and display a variety of structures. The main themes which emerge from the collective structural data available are that such compounds generally incorporate either chelating e.g. $\left[\left(\mathrm{Ph}_{3} \mathrm{AsO}\right)\left(\mathrm{NO}_{3}\right) \mathrm{Ph}_{2} \mathrm{Sn}\right]_{2} \mathrm{C}_{2} \mathrm{O}_{4}(7)$ or bridging e.g. $\left[\left(\mathrm{Bu}_{3} \mathrm{Sn}\right)_{4}\left(\mathrm{C}_{2} \mathrm{O}_{4}\right)_{3}(\mathrm{HOEt})_{2}\right]^{2 \cdot}(8)$ carboxylate functionalities. Some species e.g. $\left[\left(\mathrm{Ph}_{3} \mathrm{Sn}\right)_{3}\left(\mathrm{C}_{2} \mathrm{O}_{4}\right)_{2}\right](9)$ and $\left(\mathrm{Cy}_{3} \mathrm{Sn}\right)_{2} \mathrm{C}_{2} \mathrm{O}_{4}(10)$ contain both bonding modes, the latter example simultaneously generating isomeric five-coordinate tin environments in the same species. The chelating nature of the oxalate manifests itself through two oxygens which are cis- to the $\mathrm{C}-\mathrm{C}$ bond e.g. $\left[\left(\mathrm{Ph}_{3} \mathrm{AsO}\right)\left(\mathrm{NO}_{3}\right) \mathrm{Ph}_{2} \mathrm{Sn}_{2} \mathrm{C}_{2} \mathrm{O}_{4}(7)\right.$, formation of a fivemembered $\mathrm{SnC}_{2} \mathrm{O}_{2}$ ring being universally favoured over the four-membered $\mathrm{SnO}_{2} \mathrm{C}$ ring which would arise if each carboxylate group acted independently. Bridging behaviour arises from the two oxalate groups in unison i.e. in which the intermolecular interaction is from the opposite end of the oxalate to the nominally intramolecular $\mathrm{Sn}-\mathrm{O}$ bond e.g. [ $\left.\left(\mathrm{Ph}_{3} \mathrm{Sn}\right)_{3}\left(\mathrm{C}_{2} \mathrm{O}_{4}\right)_{2}\right]^{-}(9),\left(\mathrm{Cy} \mathrm{Sn}_{3}\right)_{2} \mathrm{C}_{2} \mathrm{O}_{4}(10)$. It would appear that no examples exist in which each end of the dicarboxylate acts as a separate bridging unit to generate parallel chains of molecules, even when the two functionalities are separated by methylene units e.g. $\left(\mathrm{Me}_{3} \mathrm{Sn}\right)_{2}$ malonate (11).

In this paper we report the structure of $\left[\mathrm{Me}_{3} \mathrm{Sn}\left(\mathrm{H}_{2} \mathrm{O}\right)\right]_{2} \mathrm{C}_{2} \mathrm{O}_{4}$, in which the oxalate shows preference for hydrogen bonding rather than bridging/chelating behaviour towards tin.

\section{Experimental}

Details of the instruments used for measuring IR (12), NMR and Mössbauer spectra (13) are given elsewhere.

\section{Synthesis of Bis-(aquatrimethylstannyl)oxalate (1)}

$\mathrm{SnMe}_{3} \mathrm{Cl}(3.00 \mathrm{~g}, 15 \mathrm{mmol})$ and $\left[\mathrm{Et}_{4} \mathrm{~N}_{2} \mathrm{C}_{2} \mathrm{O}_{4} \cdot 4 \mathrm{H}_{2} \mathrm{O}(3.17 \mathrm{~g}, 7.5 \mathrm{mmol})\right.$ were mixed in in ethanol. The resulting precipitate was recrystallised from acetonitrile to yield the title compound in $73 \%$ yield (m.p. $>235^{\circ} \mathrm{C}$ ). Analysis, found (calculated for $\mathrm{C}_{8} \mathrm{H}_{22} \mathrm{O}_{6} \mathrm{Sn}_{2}$ ): 21.4(21.3), $\mathrm{H}$ 4.92(4.92), $\mathrm{Sn}$ $52.1(52.6) \% . \operatorname{IR}\left(\mathrm{cm}^{-1}\right): 3340,3242 \mathrm{~b}\left[\mathrm{v}\left(\mathrm{H}_{2} \mathrm{O}\right)\right],\left[1635 \mathrm{vs}, 1282 \mathrm{vs}\left[\mathrm{v}_{\text {asym. svmm }}\left(\mathrm{CO}_{2}\right)\right], 549 \mathrm{~m}, 562 \mathrm{~m}\right.$ $\left[\mathrm{v}_{\text {asym }}\left(\mathrm{C}_{3} \mathrm{Sn}\right)\right], 227 \mathrm{~m}[\mathrm{v}(\mathrm{SnO})]$. Mössbauer $\left(\mathrm{mms}^{1}\right)$ : IS 1.30, QS 3.82. NMR (DMSO; $\delta$ ppm, J Hz), ${ }^{1} \mathrm{H}$ : 
$0.49\left(\mathrm{Me}_{3} \mathrm{Sn}\right),{ }^{2} \mathrm{~J}\left({ }^{117,119} \mathrm{SnH}\right) 67.7,70.2 .{ }^{13} \mathrm{C}: 0.41\left(\mathrm{CH}_{3}\right){ }^{1} \mathrm{~J}\left({ }^{117,119} \mathrm{SnC}\right) 503,528 ; 167.8(\mathrm{C}=0) .{ }^{119} \mathrm{Sn}:$ -11.8 .

\section{$X$-ray Crystallography}

A crystal of approximate dimensions $0.25 \times 0.25 \times 0.30 \mathrm{~mm}$, grown from acetonitrile solution, was used for data collection. Experimental details relating to the crystal class, method of data collection and data manipulation are given in Table 1 . In the final least squares cycles all non-hydrogen atoms were allowed to vibrate anisotropically. Hydrogen atoms were included at calculated positions where relevant, except for $\mathrm{H}(3 \mathrm{~A})$ and $\mathrm{H}(3 \mathrm{~B})$ in the co-ordinated water molecule. These hydrogens were located and refined at a distance of $0.9 \AA$ from O(3). The structure was solved using SHELX86 (14) and refined using SHELX93 (15). The asymmetric unit (shown in Fig. 1 along with the labelling scheme used) was produced using ORTEX (16). Final fractional atomic co-ordinates and equivalent isotropic thermal parameters, bond distances and angles are given in Tables 2 and 3, respectively. Tables of anisotropic temperature factors are available as supplementary data upon request from the authors.

Table 1. Crystal data and structure refinement for 1.

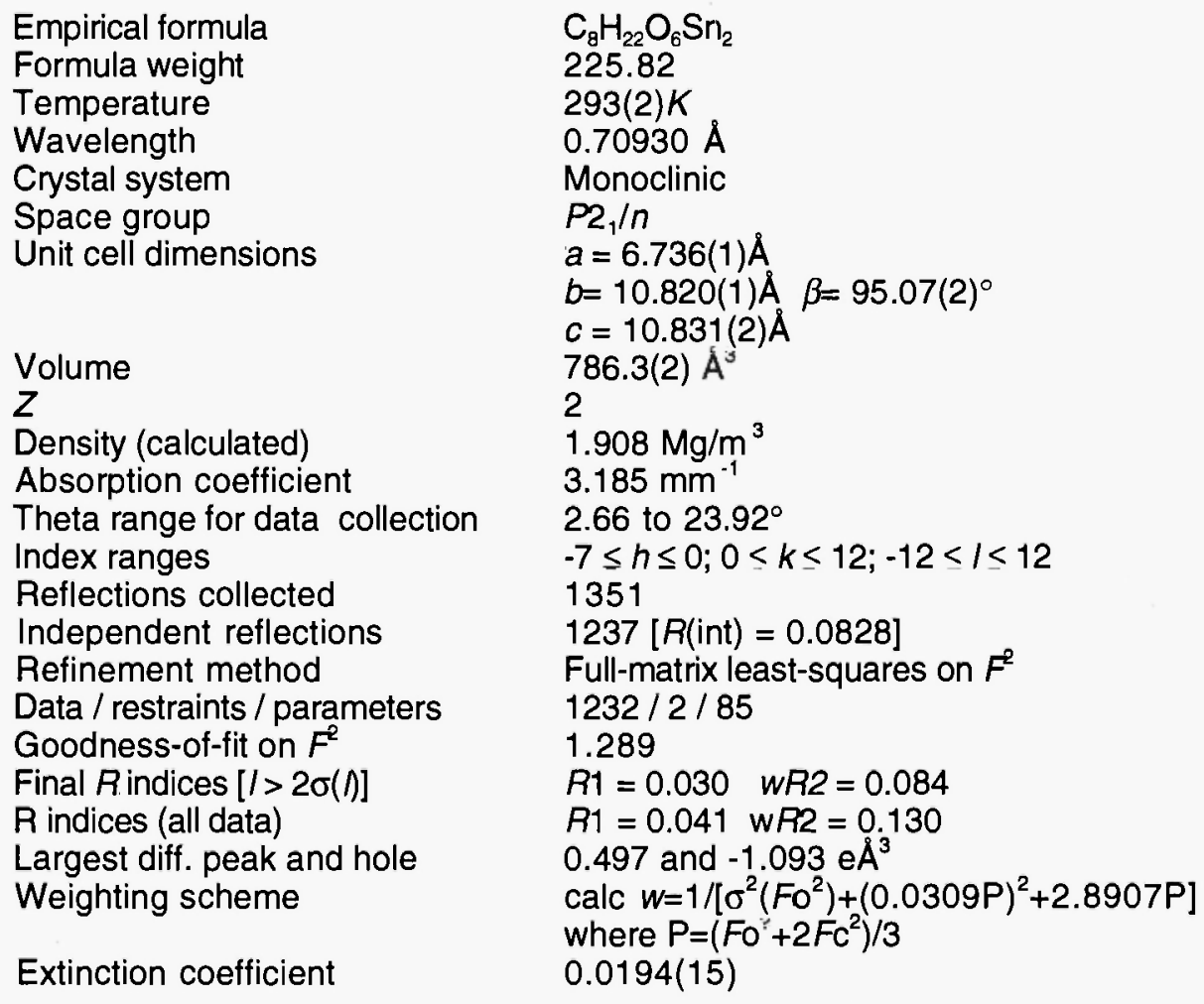

\section{Results and Discussion}

Bis-(aquatrimethylstannyl)oxalate (1) has been synthesised from the reaction of trimethyltin chloride and the tetraethyl ammonium salt of oxalic acid:

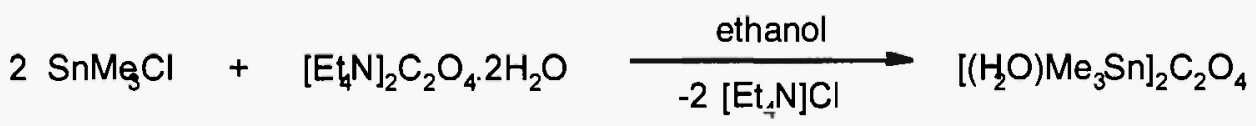

The Mössbauer spectrum of 1 consists of a simple doublet (QS: $3.82 \mathrm{mms}^{-1}$ ) consistent with (I) two tin atoms in essentially identical environments $\left(\Gamma=1.08 \mathrm{mms}^{-1}\right)$ and (ii) a trans $-\mathrm{O}_{2} \mathrm{SnC}_{3}$ coordination about the metal. In solution, the five-coordinate nature of tin is maintained based on 
the NMR evidence of ${ }^{1} \mathrm{~J}(\mathrm{SnC})>500 \mathrm{~Hz},{ }^{2} \mathrm{~J}(\mathrm{SnH})>65 \mathrm{~Hz}$ and $\delta\left({ }^{119} \mathrm{Sn}\right)(-11.6 \mathrm{ppm})$ close to that of other five-coordinate species e.g. $\mathrm{Me}_{3} \mathrm{SnCl}$ in pyridine, $\delta\left({ }^{119} \mathrm{Sn}\right)=-9 \mathrm{ppm}(17)$.

Table 2. Atomic coordinates $\left(\times 10^{4}\right)$ and equivalent isotropic displacement parameters $\left(\AA^{2} \times 10^{3}\right)$ for 1

\begin{tabular}{lllll}
\multicolumn{1}{c}{ Atom } & $\mathbf{x}$ & $\mathbf{y}$ & $\mathrm{z}$ & $\mathrm{U}(\mathrm{eq})^{\mathrm{a}}$ \\
$\mathrm{Sn}(1)$ & $789(1)$ & $2468(1)$ & $2666(1)$ & $36(1)$ \\
$\mathrm{O}(1)$ & $1253(6)$ & $955(4)$ & $4030(4)$ & $45(1)$ \\
$\mathrm{O}(2)$ & $-1974(6)$ & $657(5)$ & $4098(5)$ & $65(2)$ \\
$\mathrm{O}(3)$ & $418(8)$ & $4192(6)$ & $1277(6)$ & $81(2)$ \\
$\mathrm{C}(1)$ & $-668(12)$ & $3613(7)$ & $3876(8)$ & $64(2)$ \\
$\mathrm{C}(2)$ & $3904(11)$ & $2644(8)$ & $2584(9)$ & $67(2)$ \\
$\mathrm{C}(3)$ & $-767(14)$ & $1426(10)$ & $1254(8)$ & $81(3)$ \\
$\mathrm{C}(4)$ & $-251(8)$ & $456(5)$ & $4464(6)$ & $36(1)$ \\
$\mathrm{H}(3 \mathrm{~A})$ & $1470(92)$ & $4386(95)$ & $857(81)$ & $113(37)$ \\
$\mathrm{H}(3 \mathrm{~B})$ & $-834(88)$ & $4366(157)$ & $966(147)$ & $213(75)$
\end{tabular}

${ }^{a} \mathrm{U}(\mathrm{eq})$ is defined as one third of the trace of the orthogonalized Uij tensor.

The Mössbauer spectrum of 1 consists of a simple doublet (QS: $3.82 \mathrm{mms}^{-1}$ ) consistent with (I) two tin atoms in essentially identical environments $\left(\Gamma=1.08 \mathrm{mms}^{-1}\right)$ and $(i i)$ a trans $-\mathrm{O}_{2} \mathrm{SnC}_{3}$ coordination about the metal. In solution, the five-coordinate nature of tin is maintained based on the NMR evidence of ${ }^{1} \mathrm{~J}(\mathrm{SnC})>500 \mathrm{~Hz},{ }^{2} \mathrm{~J}(\mathrm{SnH})>65 \mathrm{~Hz}$ and $\delta\left({ }^{119} \mathrm{Sn}\right)(-11.6 \mathrm{ppm})$ close to that of other five-coordinate species e.g. $\mathrm{Me}_{3} \mathrm{SnCl}$ in pyridine, $\delta\left({ }^{119} \mathrm{Sn}\right)=-9 \mathrm{ppm}(17)$.

Table 3. Bond lengths $[\AA]]$ and angles $[\infty]$ for 1.

\section{Bond lengths}

Sn(1)-C(3)

Sn(1)-C(1)

Sn(1)-C(2)

Sn(1)-O(1)

\section{Bond Angles}

$\mathrm{C}(3)-\mathrm{Sn}(1)-\mathrm{C}(1)$

$\mathrm{C}(3)-\mathrm{Sn}(1)-\mathrm{C}(2)$

$C(1)-S n(1)-C(2)$

$C(3)-S n(1)-O(1)$

$C(1)-S n(1)-O(1)$

C(2)-Sn(1)-O(1)

$\mathrm{C}(3)-\mathrm{Sn}(1)-\mathrm{O}(3)$
2.103(8)

$2.108(7)$

$2.117(7)$

2.209(4)

$122.5(4)$
$116.8(4)$
$119.4(4)$
$97.0(3)$
$93.8(3)$
$90.7(2)$
$86.7(3)$

$\begin{array}{ll}\mathrm{Sn}(1)-O(3) & 2.395(5) \\ O(1)-C(4) & 1.273(7) \\ O(2)-C(4) & 1.212(7) \\ C(4)-C\left(4^{\prime}\right) & 1.540(12)\end{array}$

$C(1)-S n(1)-O(3)$
$C(2)-S n(1)-O(3)$
$O(1)-S n(1)-O(3)$
$C(4)-O(1)-S n(1)$
$O(2)-C(4)-O(1)$
$O(2)-C(4)-C\left(4^{\prime}\right)$
$O(1)-C(4)-C\left(4^{\prime}\right)$

84.5(3)

87.3(2)

176.3(2)

119.4(4)

$125.0(6)$

120.1(6)

114.9(6)

Symmetry transformation used to generate equivalent (primed) atoms: $-x,-y,-z+1$

From the crystallographic study, 1 is centrosymmetric by virtue of an inversion centre at the midpoint of the oxalate $\mathrm{C}-\mathrm{C}$ bond, with each carboxylic acid functioning as a monodentate ligand with respect to tin. In addition, each tin coordinates a water of crystallisation to generate a trans $-\mathrm{O}_{2} \mathrm{SnC}_{3}$ trigonal bipyramidal coordination sphere about the metal (Figure 1). Although the oxygen of the oxalate is bound more strongly that the water as expected [Sn(1)-O(1): 2.209(3); $S n(1)-O(3)$ : 2.395(5) $\AA$ ], the coordination sphere about tin is regular, as evidenced by the near linearity of the $\mathrm{O}(1)-\mathrm{Sn}(1)-\mathrm{O}(3)$ unit $\left[176.3(2)^{\circ}\right.$ ]. In addition, the three $\mathrm{C}-\mathrm{Sn}-\mathrm{C}$ angles within the equatorial plane are also close to the ideal angle of $120^{\circ}\left[116.8(4)-122.5(4)^{\circ}\right]$. The monodentate nature of the carboxylic acid group manifests itself in two quite distinct $\mathrm{C}-\mathrm{O}$ bond lengths, corresponding to one single $[C(4)-O(1): 1.273(7) \AA]$ and one double bond $[C(4)-O(2): 1.212(7) \AA]$. 


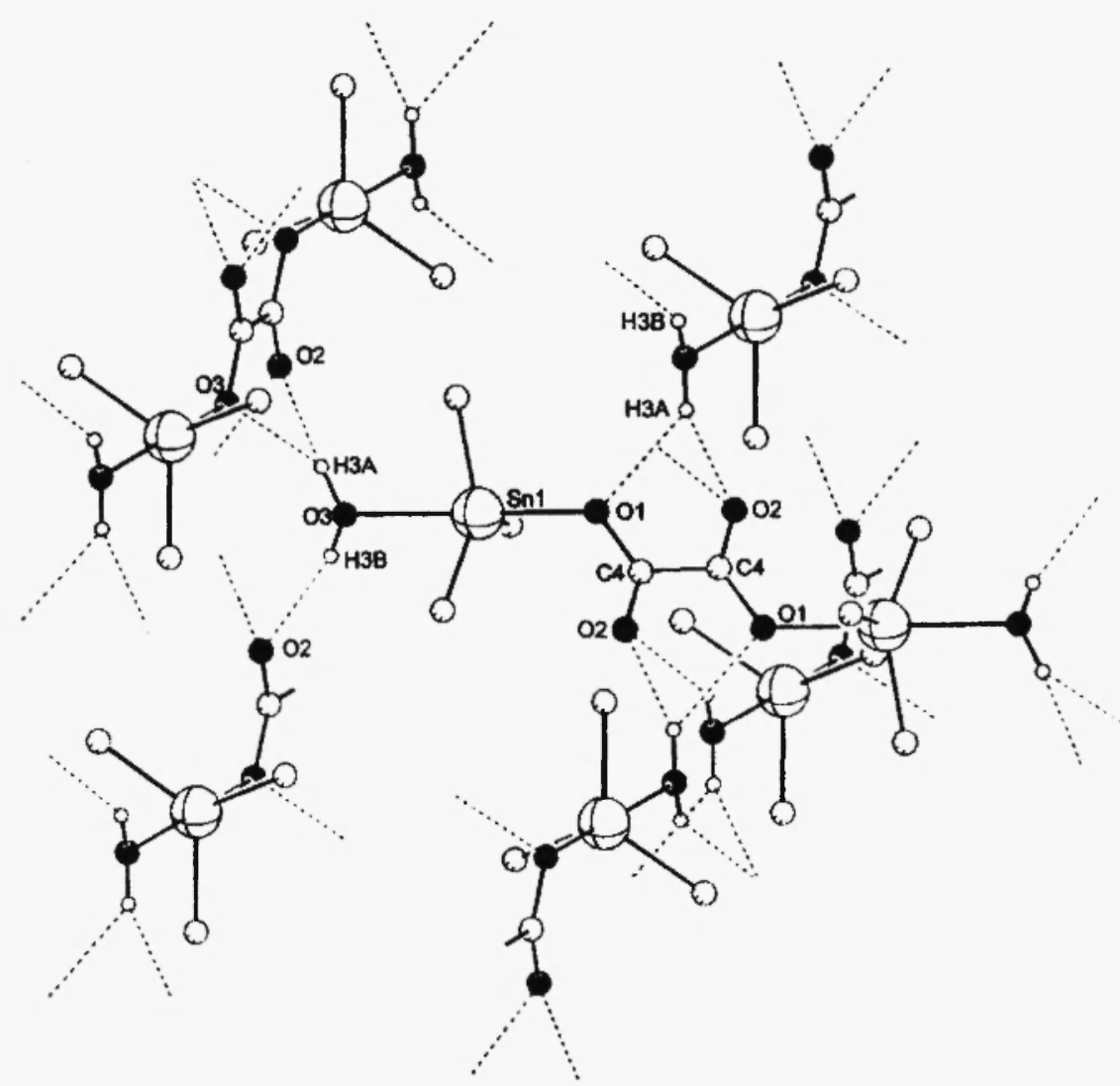

Figure 1 The structure of 1 showing the labelling scheme used in the text and tables, along with the hydrogen bonds (dotted lines) involving coordinated water and the oxalate ligand.

The lattice structure of 1 is dominated by a network of weak hydrogen bonds involving the coordinated water molecules. $\mathrm{H}(3 \mathrm{~A})$ forms a pair of hydrogen bonds with $\mathrm{O}(1)[\mathrm{O}(1)-\mathrm{H}(3 \mathrm{~A}): 2.28(8)]$ and $\mathrm{O}(2)[\mathrm{O}(2)-\mathrm{H}(3 \mathrm{~A}): 2.26(5) \AA]$ of neighbouring molecules, while $H(3 B)$ is bonded to only $\mathrm{O}(2)$ $[\mathrm{O}(2)-\mathrm{H}(3 \mathrm{~B}): 2.03(10) \mathrm{A}]$ from adjacent units. (Figure 1) Notably, the hydrogen bonds involving the doubly-bound oxygen $[O(2)]$ are stronger than those involving the singly-bound oxygen $[O(1)]$. These intermolecular interactions collectively generate a three-dimensional network which has pseudo four-fold symmetry (Figure 2).

Thus, unlike other organotin oxalates, the title compound has a lattice structure dominated by hydrogen bonds, and an oxalate ligand which hydrogen bonds to coordinated water molecules in preference to adjacent metal centres.

\section{Acknowledgements}

The Senegalese group thanks Prof. M Vidali (University of Padua, Italy) for equipment support and the Third World Academy of Science (Trieste, Italy) for financial support. 


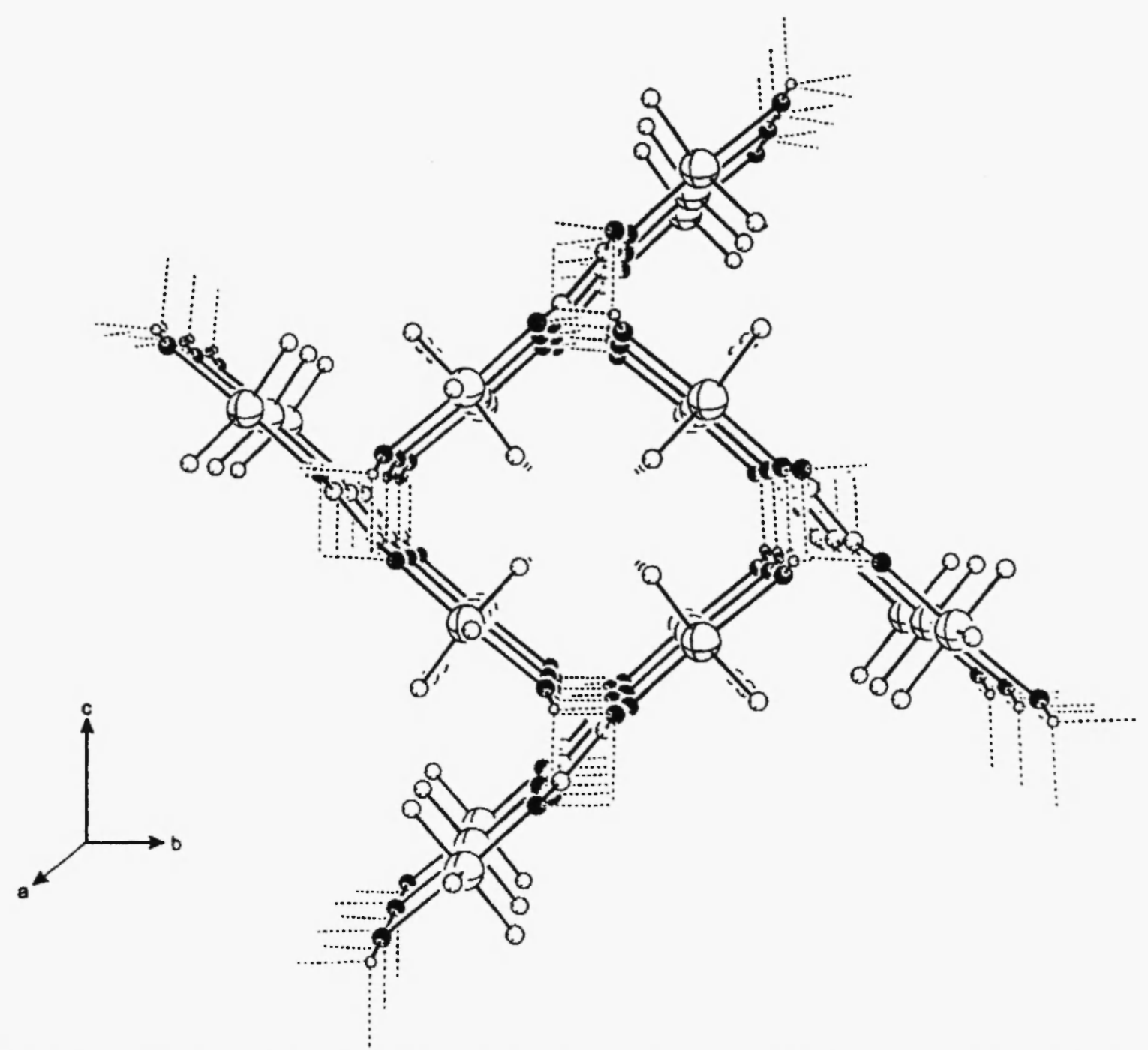

Figure 2 The unit cell of 1 viewed perpendicular to the $b c$ plane, showing the pseudo four-fold hydrogenbonded arrangement (dotted lines) inherent in the structure.

\section{References}

1. E. R. T. Tiekink, J. Organomet. Chem, 1986, 302, C1.

2. J. Kummerlein, A. Sebald and H. Reuter, J. Organomet. Chem., 1993, 427, 309.

3. R. E. Drew and F. W. B. Einstein, Acta Cryst., 1979, B28, 345.

4. K. C. Molloy, K. Quill, D. C. Cunningham, P. McArdle and T. Higgins, J. Chem. Soc., Dalton Trans., $1989,267$.

5. A. Diasse-Sarr, L. Diop, M. F. Mahon and K. C. Molloy, Main Group Met. Chem., 1997, 20, 223.

6. O. Gueye, H. Qamar, L. Diop, C. A. Diop and U. Russo, Polyhedron, 1993, 12, 1245.

7. C. Pelizzi, G Pelizzi and P. Tarasconi, J. Chem. Soc., Dalton Trans., 1983, 2689.

8. S.-W. Ng, V. G. Kumar Das, M. B. Hossain, F. Goerlitz and D. van der Helm, J. Organomet. Chem., 1990, 390, 19.

9. S.-W. Ng and V. G. Kumar Das, J. Organomet. Chem., 1993, 456, 175.

10. S.-W. Ng, V. G. Kumar Das, S.-L. Li and T. C. W. Mak, J. Organomet. Chem., 1994, 467, 47.

11. U. Schubert, J. Organomet. Chem., 1978, 155, 285.

12. A. S. Sall, A. Diasse, O. Sarr and L. Diop, Main Group Met. Chem., 1992, 6, 15.

13. K. C. Molloy, T. G. Purcell, K. Quill and I. W. Nowell, J. Organomet. Chem., 1984, 267, 237. 
14. G. M. Sheldrick, Acta Crystallogr.,1990, A46, 467.

15. G. M. Sheldrick, SHELX93, A program for crystal structure refinement, University of Göttingen, 1993.

16. P. McArdle, J. Appl. Cryst., 1994, 27, 438.

17. A. G. Davies and P. J. Smith, Comprehensive Organometallic Chemistry, Pergamon Press, 1982 , p. 527.

Received: June 27, 1997 - Accepted: July 4, 1997 -

Accepted in revised camera-ready format: July 18, 1997 